Doi: $10.4274 /$ Vhd. 44153

\title{
Erzurum ili ve Çevresindeki Kan Donörlerinde Hepatit B Seroprevalansi
}

\author{
Seroprevalance of Hepatitis B Among Healty Blood Donors in Erzurum Region
}

\author{
Ahmet UYANIKOĞLU1, Muharrem COŞKUN2, Fatih ALBAYRAK3, Ferda AKTAŞ4, \\ Doğan Nasır BINICl5, Yasin ÖZTÜRK5 \\ ${ }^{1}$ Harran Üniversitesi Tıp Fakültesi, Gastroenteroloji Anabilim Dalı, Şanlıurfa, Türkiye \\ 2Istanbul Eğitim ve Araştırma Hastanesi, Gastroenteroloji Bölümü, Istanbul, Türkiye \\ ${ }^{3}$ Erzurum Bölge Eğitim Hastanesi, Gastroenteroloji Bölümü, Erzurum, Türkiye \\ ${ }^{4}$ Erzurum Bölge Eğitim Hastanesi Mikrobiyoloji Bölümü, Erzurum, Türkiye \\ ${ }^{5}$ Erzurum Bölge Eğitim Hastanesi, lç Hastalıkları Bölümü, Erzurum, Türkiye
}

ÖZET

Amaç: Hepatit B virüsüne bağlı kronik hepatit dünya ve ülkemiz için önemli bir sağılı sorunudur. Son çalışmalarda Türkiyede HBsAg pozitiflik sıkı̆̆ı \%4 olarak bildirilmiş olup, ülkemizin orta endemik bölgede olduğu bildirilmiştir. Sağıkı donör kanlarında hepatit B virusu $\mathrm{HBsAg}$ ve anti-HBs testi ile araştırımaktadır. Bu çalışmanın amacı Erzurum ve çevresinde sağ|lılı kan donörlerinde HBsAg ve antiHBs sıkı̆̆ını araşııımaktır.

Gereç ve Yöntemler: 2009-2010 Haziran ayları arasında hastanemiz kan bankasına bağışta bulunan gönüllülerdeki HBsAg ve anti-HBsAg pozitifliği retrospektif olarak araştırılmıştır. Bu amaçla tüm donörlere rutin olarak yapılan HBsAg ve anti-HBs test sonuçları gözden geçirilmiştir. HBsAg ve Anti-HBs ELISA yöntemi ile çalışılmışır.

Bulgular: Yaklaşık 1 yılda HBsAg pozitif saptanan toplam hasta sayısı 4/463 $(\% 0,9)$, Anti-HBsAg pozitif saptanan hasta sayısı $167 / 463(\% 36)$ idi. Donörlerden 52 'si kadın (\%11), 411'i (\%89) erkek idi. HBsAg'si pozitif olan hastaların tamamı erkekti. Anti-HBs pozitif olan hastaların 21'i kadın (\%12), 146'sı (88) erkek idi.

Sonuç: Erzurum ve çevresinde kan donörlerinde HBsAg sıklı̆ı yaklaşık \%1 olup Türkiye ortalamasının altındadır, anti-HBs sıklı̆ı yaklaşı \%36'dır. Bu bulgular bölgemizin düşük endemisitede olduğunu düşündürmektedir. (Viral Hepatit Dergisi 2012; 18(3): 91-3)

Anahtar Kelimeler: Hepatit B, seroprevalans

\section{ABSTRACT}

Objective: Hepatitis B virus-related chronic hepatitis is a major health problem in the world and for our country. The frequency of HBsAg positivity was $4 \%$ in recent studies has been reported in Turkey, our country is medium endemic region. Healthy blood donors are investigated with hepatitis B virus HBsAg and anti-HBs test. The purpose of this study to investigate the frequency of HBsAg and anti-HBs in healthy blood donors in Erzurum Region.

Materials and Methods: Who HBsAg and anti-HBsAg positive volunteers in donors of blood bank, were investigated retrospectively between 2009-2010 to June . To this end, in all donors routinely performed HBsAg and anti-HBs test results are reviewed. The total number of patient was 463 at screening. $\mathrm{HBs} A g$ and anti-HBs was assayed by ELISA.

Results: Approximately in 1 year, the total number of patients who were identified HBsAg positive were 4 / $463(0.9 \%)$, the number of patients who were identified anti-HBsAg positive were 167/463 (36\%) respectively. Donors were 52 women $(11 \%), 411$ 'i $(89 \%)$ were male. All of the patients who were positive for $\mathrm{HBsAg}$ were men. Anti-HBs positive patients were 21 women (12\%), 146 (88) were male. Conclusion: Between 2009 and 2010 among blood donors in Erzurum Region, the frequency of HBs-Ag is approximately $1 \%$, below the average of Turkey. AntiHBsAg positive were $36 \%$. These findingd suggest that our region is a low endemic region. (Viral Hepatitis Journal 2012; 18(3): 91-3)

Key words: Hepatitis B, seroprevalance 


\section{Giriş}

Hepatit B Virüsü (HBV) akut hepatitin yanı sıra kronik hepatit, karaciğer sirozu ve hepatoselüler karsinomaya yol açması nedeniyle tüm dünyada olduğu gibi özellikle ülkemiz gibi gelişmekte olan ülkelerde de önemli bir sağlık sorunudur. Bu nedenle bu virüslerle mücadelede başarılı olmak için epidemiyolojinin iyi bilinmesi gerekir (1). Tek rezervuarı insan olan HBV'nin yayılmasında taşıyıcılık kavramı oldukça önemlidir (2). Bugün dünyada yaklaşık 350 milyon kişinin kronik HBV taşıyıcısı olduğu tahmin edilmektedir. Ülkemizde ise bölgeden bölgeye endemisite değişikliğiyle beraber 3 milyon civarında HBV taşıyıcısı bulunduğu tahmin edilmektedir (3). HBV epidemiyolojisi ülkelerin gelişmişlik düzeyiyle ilgili özellikler göstermektedir (1).

Hepatit B enfeksiyonu bildirimlerine 1990 yılında başlanmıştır. 1996 yılında kurulan Bağışıklık Danışma Kurulu hepatit B aşııının rutin çocuk aşılama programlarına dahil edilmesini tavsiye etmiştir. Kurul aynı zamanda sağlık personeline ve yüksek risk gruplarına devamlı olarak aşı uygulamasının yapılmasını önermiştir. Yapılan bildirimlerin sonuçlarına göre; hepatit B morbiditesinde 1990-2000 yılları arasındaki dönemde yavaş bir artış saptanmış olup, olgular en fazla cinsel olarak aktif ve fertil olunan 25-44 yaş grubu arasında görülmektedir. Kızılay Kan Merkezlerinden kan bağışı yapanlar üzerindeki taramalarda HBsAg seropozitivitesi 1985-89 yıllarında 4,71 iken, 1990-95 yılları arasında \%5,11'e yükselmiştir. Bu durum enfeksiyonun kendine özgü durumunu muhafaza ettiğini göstermektedir (4).

Türk Karaciğer Araştırmaları Derneği 2010 yılında Türkiye çapında yaptığı araştırmaya göre hepatit B virusu taşıyıcılığını temsil eden HBsAg pozitifliği \%4, Hepatit B virusuna karşı bağışıklık durumunu gösteren anti-HBs pozitifliği \%32 olarak bulunmuştur (5).

$\mathrm{Bu}$ çalışmanın amacı hastanemize başvuran sağlıklı kan donörlerinde HBsAg ve anti-HBs sıklığını araştırmaktır.

\section{Gereç ve Yöntemler}

2009-2010 Haziran ayları arasında hastanemiz kan bankasına bağışta bulunan gönüllülerdeki HBsAg (hepatit B yüzey antijeni) ve anti-HBsAg (hepatit B yüzey antikoru) pozitifliği retrospektif olarak araştırımıştır. Bu amaçla tüm donörlere rutin olarak yapılan HBsAg ve anti-HBs test sonuçları gözden geçirilmiştir. HBsAg ve Anti-HBs ELISA yöntemi ile çalışılmıştır. Istatistiki analiz için 17. sürüm SPSS programı kullanılmıştır.

\section{Bulgular}

Yaklaşık 1 yılda HBsAg pozitif saptanan toplam hasta sayısı 4/463 (\%0,9), Anti-HBsAg pozitif saptanan hasta sayısı 167/463

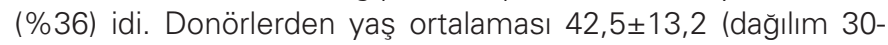
61), 52'si kadın (\%11), 411'i (\%89) erkek idi. HBsAg'si pozitif olan hastaların tamamı erkekti. HBsAg'si pozitif olan hastaların tamamında AST ve ALT düzeyleri normal olup, önceden HBsAg pozitifliği bilinmiyordu ve bu hastaların taşıyıcı olduğu düşünüldü. Anti-HBs pozitif olan hastaların 21'i kadın (\%12), 146'sı (\%88) erkek idi (Tablo 1).

\section{Tartışma}

Tek rezervuarı insan olan Hepatit $B$ Virüsünün (HBV) yayılmasında taşıyıcılık kavramı oldukça önemlidir (2) Bugün dünyada yaklaşık 350 milyon kişinin kronik HBV taşıyıcısı olduğu tahmin edilmektedir (3) Ülkemizde ise bölgeden bölgeye endemisite değişikliğiyle beraber 3 milyon civarında HBV taşıyıcısı olduğu tahmin edilmektedir (3) HBV enfeksiyonu dünyadaki dağılım farklılıkları nedeniyle düşük, orta ve yüksek endemisite bölgelerine ayrılmıştır. Taşıyıcılık oranı \%2'den az olan ülkeler düşük, \%2-10 arası orta, \%10'dan fazla olan ülkeler yüksek endemik bölge kapsamına alınmıştır. Ülkemizin de içinde bulunduğu orta doğuda HBsAg pozitifliği \%2-10 arasında olduğu için ülkemizde orta endemisite profili izlenmektedir (1).

Kan veren ve sağlıklı yetişkin 1,2 milyon insanı kapsayan bir çalısmanın analizinde HBsAg pozitivitesi insidansının yaklasık \%6 oldugu rapor edilmistir (6). Bazı risk gruplarında hepatit B seroprevalansına dair bir başka çalışma seropozitivitenin $\mathrm{HBsAg}$ pozitif ve Anti-HBs pozitif kayıtlı seks çalışanlarında \%52,1, homoseksüellerde \%41,2, hastane çalısanlarında \%41,2 ve denetleme kümesinde \%26,2 olduğunu göstermiştir (7).

Yaptığımız çalışmada ise Erzurum ve çevresinde HBsAg sıklığı yaklaşık \%1 olup literatüre ve Türkiye verilerinden daha az sıklıktadır. Bu veriler bölgemizin düşük endemik bölge kapsamında olduğunu düşündürmektedir.

Türk Karaciğer Araştırmaları Derneği (TKAD)'nin 2010 yıında Türkiye çapında yaptığı araştırmaya göre Türkiyede 3 milyon hepatit B'li kişi olduğu hesaplanmıştır. Hepatit B virusu taşıyıcılığını temsil eden HBsAg pozitifliği \%4, Hepatit B virusuna karşı bağışıklık durumunu gösteren anti-HBs pozitifliği \%32 olarak bulunmuştur. Bölgelere göre HBsAg pozitiflik

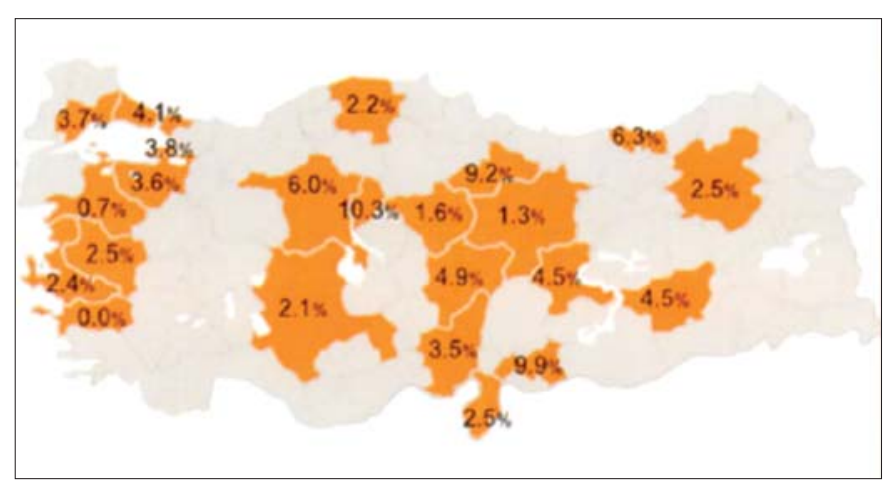

Şekil 1. Bölgelere göre HBsAg (Hepatit B yüzey antijeni) pozitiflik oranları

\begin{tabular}{lccc}
\multicolumn{4}{l}{ Tablo 1. Serolojik göstergelerin yaş ve cinsiyet dağıııı } \\
\hline & Erkek & Kadın & Toplam \\
\hline HBsAG $(+)$ & $4(\% 0,9)$ & 0 & 4 \\
Anti-HBs $(+)$ & $146(\% 88)$ & $21(\% 12)$ & $167(\% 36)$ \\
Anti-HBs (-) & 261 & 31 & 292 \\
Toplam & $411(\% 89)$ & $52(\% 11)$ & 463
\end{tabular}


oranları HBV'nin en fazla görüldüğü bölgeler Orta ve Güneydoğu Anadolu Bölgesi, en az görüldüğü bölgeler ise Ege ve lç Anadolu'nun doğu bölgesidir. Bu çalışmanın yürütüldüğü illerden biri olan Erzurum'da HBsAg pozitifliği \%2,5 oranında bulunmuştur (Şekil 1). Ayrıca Hepatit B erkeklerde daha sık görülmektedir. Yaptığımız çalışmada ise Doğu Anadolu (Erzurum) Bölgesinde HBsAg sıklığı yaklaşık \%1 olup TKAD'ın çalışmasına göre daha düşük sıklıkta saptanmıştır (5). Bunun sebeplerinden biri de HBsAg taşıyıcılığı bilinen kişilerin istemli olarak donör olmamaları olabilir. TKAD yaptığı araştırmada antiHBsAg sıklığını \%32 oranında saptanmıştır (5) Çalışmamızda saptadığımız \%36'lık oranla uyumludur. TKAD'ın çalışmasında erkek cinsiyetinde pozitiflik oranının daha yüksek olması, (5) çalışmamızda HBsAg pozitif kişilerin tamamının erkek olması ile kısmen paralel bir bulgu idi. Ayrıca bölgemizde donörlerin sıklıkla erkek olmasının bu sonucun çıkmasına neden olduğu düşünülmüştür.

HBV akut hepatitin yanı sıra kronik hepatit, karaciğer sirozu ve hepatoselüler karsinomaya yol açması nedeniyle tüm dünyada olduğu gibi özellikle ülkemiz gibi gelişmekte olan ülkelerde de önemli bir sağlık sorunudur. Bu nedenle bu virüsle mücadelede başarılı olmak için epidemiyolojinin iyi bilinmesi gerekir. Yaptığımız çalışmada, Erzurum ve çevresinde HBsAg sıklığı yaklaşık \%1 saptanmış olup, literatüre ve son Türkiye verilerinin aksine, bölgemizin orta endemisite değil, düşük endemik bölge kapsamında olduğu düşünülmüştür.

\section{Kaynaklar}

1. Madendağ $Y$, Çöl Madendağ $I$, Çelen $S$, Ünlü $S$, Danışman N. Seroprevalence Of Hepatitis B, Hepatitis C And HIV At Whole Obstetrıc And Gynecologic Patients Who Applied Our Hospital. Turkiye Klinikleri J Gynecol Obst. 2007; 17: 442-6.

2. Tasyaran MA. HBV enfeksiyonu epidemiyolojisi. Kılıçturgay K, Badur S editörler. Viral hepatit 2001 Istanbul: Viral hepatitle savaşım derneği; 2001; 121-128.

3. Baykır M, Uysal H. Kan ve kan komponentlerinin transfüzyonu. 1.baskı. Konya 2002.

4. Akın L. Epidemiology Of Sexually Transmitted Infection: Review. Turkiye Klinikleri J Med Sci. 2006; 26: 655-65.

5. Türk Karaciğer Araştımaları Derneği Hepatit B prevalans Calıșması 2010

6. Kebudi R, Ayan I, Yılmaz G, Akıcı F, Görgün Ö, Badur S. Seroprevalence of hepatitis $b$, hepatitis $c$ and HIV infections in children with cancer at diagnosis and following therapy in Turkey. Med Pediatr Oncol. 2000; 34(2): 102-5.

7. Aral SO. Holmes KK. Sexually Transmitted Diseases in the AIDS Era. Sci Am. 1991; 264(2): 62-9. 